Bacteriological Study of the Bacteria Cause Urinary Tract Infection of Patients Admitted to Cardiac Care Unite a

\title{
Bacteriological Study of the Bacteria Cause Urinary Tract Infection of Patients Admitted to Cardiac Care Unite a Baqubah General Teaching Hospital
}

Hanan Thamer Najim(Msc) ${ }^{1}$, Abbas Abod Farhan $(\mathrm{PhD})^{2}$ and Ahmed Methab

Athab $(\mathrm{PhD})^{3}$

\begin{abstract}
Background:Urinary tract infection patient Urinary Tract Infection ( UTI ) one of commonest types of patient admitted to CCU ( cardiac care unit ) of other medical wards this is occur directly from contact to infected hand or material or during catheterization.

Objective:To evaluation common bacterial cause UTI in patients admitted Cardiac Care Unite to show the antimicrobial agent and bacteria resistant and production the biofilm.

Patients and Methods: Collection of samples from urine aseptically for culture.Isolation and identification of uropathogens using biochemical tests and testing ability of these bacterial isolation for virulence production and testing the antimicrobial susceptibility test.

Results: It is A total of 135 catheter samples were collected from patient (135) catheter samples from patients in CCU at Baqubah General Teaching Hospital for the period from 1st November 2016 to 1st March 2017 frommales and female, and the samples and cultured on the medium blood agar and MacConkey agar. Then growing bacterial farms subjected to microscopic and biochemical tests for the diagnosis of bacteria. Escherichia coli with a ratio $31.8 \%$, and (20)isolations of Proteus mirabilis with a ratio $18.2 \%, 16$ isolates of Klebsiella pneumonia, (14) isolations of Pseudomonas aeruginosa with a ratio $12.7 \%$.The Antimicrobial sensitivity is investigated for (9) antibiotics from different groups including; The results show a high resistance to most of the antibiotics under study, and resistance all isolates ware of Aztreonam ,Cefotaxime , Co-Trimoxazol with ratio $95 \%$, Naldixic acid with ratio 100\%, Tetracycline $75 \%$, Gentamycin $70 \%$ and Antimicrobial sensitivity to antibiotics to Amikacin $45 \%$ followed by Ciproflaxcin $50 \%$ and tobramycin $80 \%$. All kinds of bacteria were produced in biofilm in the ELISA method with a ratio $100 \%$, while Congo red with a ratio $50 \%$. Conclusion: It was observed that multiple antibiotic resistance was common among local isolates of the bacteria under study and Biofilms are important in protecting the bacteria inside the catheter from antibiotics.

Key words: Gram Negative bacteria, Antibiotics ,Biofilm ,Urinary Tract Infection , cardiac care unit.
\end{abstract}

Corresponding Author: hananthamer984@gmail.com

Received: $29^{\text {th }}$ August 2017

Accepted: $24^{\text {th }}$ September 2017

https://doi.org/10.26505/DJM.

\footnotetext{
${ }^{1,2}$ Biology Department- College of Education for Pure Sciences- University of Diyala- Diyala- Iraq.

${ }^{3}$ College of Medicine- Diyala University- Diyala -Iraq.
} 
Bacteriological Study of the Bacteria Cause Urinary Tract Infection of Patients Admitted to Cardiac Care Unite a

\section{Introduction}

Urinary Tract Infections are one of the most common health problems in most countries of the world, followed by Respiratory Tract Infection [1]. UTIs are all age groups of males and females. One of the main causes of infant death is what referred by [2], as well as older males are also infected because most of them are exposed to prostates infection, which causes slow discharge of the bladder from the arteries, which cause inflammation of the urinary tract [3]. Older women also suffer from urinary tract infection largely because of hormonal changes due to aging, immunosuppression [3], pregnant women, and patients with chronic diseases such as diabetics or Immunosuppressed or weakened in immunization due to HIV infection or cancer. All of the above increases the risk of urinary tract infection [3]. UTI is the most common infection of hospital Nosocomial Infections by $20 \%-30 \%$ in the cardiac care unit [4]. Bacteria, the main cause of UTIs, are 95\% [5] and usually bacteria that live in the Digestive Tract, as well as in the vagina or around the urethra which are at the forefront of the urinary tract. Most of these bacteria enter the urethra and are transferred to the bladder and kidneys. Clinical injury is usually caused by Gram-positive bacteria and Gram positive bacteria despite fungi, viruses and parasites [6]. It can also be caused by a common cause of urinary tract infection non-bacterial hemorrhagic infections include hemorrhagic cystitis, for example, with viruses such as adenovirus [7].Common pathogenic bacteria pathogens in the intensive care unit include Gram Negative bacteria such as Escherichia, Klebsiell, Proteus, Enterobacter, Pseudomonas, Serratiaspp and Gram positive bacteria such as Streptococci, Enterococcus sp.and Staphylococcus [8].

The main cause of Uropathogen in the world is Escherichia coli (U P E C), which is $80 \%-85 \%$ according to [9]. Antibiotic resistance by the bacteria that cause urologic infections has become known throughout the world, which has been increasing, especially for the widely used antibiotics. This has led to resistance of bacteria to these antibiotics by developing defensive mechanisms against them, and there is a correlation between increased resistance and antibiotic use by patients ,These bacteria may produce Virulence Factors such as biofilm, Which is related to the presence of the catheter because it is a suitable environment for germs, which are suitable for the formation of the biofilm[10].

\section{Patients and Methods}

Use media such as MacConkey agar, Blood agar, nutrient agar, and the of the MullerHinton agar, types of antibiotics; Aztreonam, Cefotaxime, Gentamycin, Amikacin, Tobramycin, Naldixic acid, Ciprofloxacin and Tetracycline. Co-trimoxazole agents are used, as shown in Table 3, and the biofilm production in the environment of the CongoRed method, the environment is prepared as it mentioned in [11].

\section{Isolation and Diagnosis of Bacteria}

It is a total of (135) collected from patients in the intensive care unit at Baqubah General 
Teaching Hospital for the period from 1st November 2016 to 1st March 2017, and were directly grown on the blood agar and MacConkey for the purpose of distinguishing between positive isolates and Gram-negative isolates were purified on the center of nutritious agar in a planning manner, and then the identification, phenotypic, and biochemical tests were performed for bacterial isolates. The bacterial isolates under study were identified according[12]. The colonies were initially identified as dependent on the phenotypic traits, including the shape, color, texture, smell, and size of the colonies on the central blood agar and MacConkey centers. In addition to its ability to analyze red blood cells on the blood agar center, the bacterial isolates under study were subjected to microscopic examination by taking a small swab of the colony and transmitting it to the glass slide and dye it with a gram dye to see the type of pigment and the shape of the cells and the way they are collected [13].

\section{Antibiotic susceptibility test}

The sensitivity of isolates under study was tested for 9 antibiotic agents, they were distributed among the $\beta$-Lactam antibiotic that included Aztreonam, Cefotaxime, also from Aminoglycosides antibiotics group, Gentamycin, Amikacin, Tobramycin, Quinolone Naldixic acid, Ciprofloxacin, and other anti-tetracycline such as CoTrimoxazol anti-folic acid was used to measure the diameter of the inhibition area for the collection of antibodies used in the study compared to the [14]. The sensitivity test was performed using the antibiotic pill method Kirby -boure test [15].

1.Pour $5 \mathrm{ml}$ of nourishing broth into 2-3 colonies of 24-hour pure bacterial farms.

2.Bake well, and incubate at $37^{\circ} \mathrm{C}$ for 24 hours.

3.The growth curve was measured using the standard turbidity constant to give an approximate number of $1.5 \times 108$ cells $/ \mathrm{ml}$. 4.Transfer $0.1 \mathrm{~mL}$ of bacterial suspension and spread to the center of Akar Muller Hinton, leave the dish for 5 minutes at room temperature until the plant is dried.

5.Transfer antibiotic tablets to the middle surface of the plant using sterile forceps at a rate of 9 tablets per dish.

6.The dishes were incubated at $37^{\circ} \mathrm{C}$ for $24-$ 18 hours. After measuring the diameters of the inhibition zones around each disc, the sensitive bacteria (S), R (R), or intermediate (I).

\section{Biofilm production Test}

\section{a)Congo-red Method}

A pure single colony was transferred to the nutrient agar medium to a test tube containing $5 \mathrm{ml}$ of the prepared salt solution. After a good mixing with the carburetor, the mass was compared to the prepared McFarland's[0.5], the prepared Concorde fertilized and the dishes was incubated at 37 ${ }^{\circ} \mathrm{C}$ for $24-48$ hours. The result is positive when the colonies appear black with a dry crystalline density, while the negative result remains the colonies pink [16].

\section{b)Biofilm production by ELISA test}

1.(4 - 3) colonies of bacteria at the age of 48-24 hours, and then vaccinated tubes 
container (10-5) $\mathrm{ml}$ of heart-brain diffusion broth placed in the incubator at $37^{\circ} \mathrm{C}$ for 24 hours, hour.

2.Centrifuge the tubes to get rid of the medium and get the bacterial suspension. Wash the cells with sterile normal saline solution twice.

3.Place 180 microliters of the flat-bottomed tissue culture plate, each for two isolates and then add 20 microliters from the microbial suspension to the holes for each isolation. Three holes were left in control, with 200 microliters placed from the center of the heart-piercing broth and the non-pollinated brain.

4.Cover the dish with a clean paper and a Para Film and incubate at a temperature of $37^{\circ} \mathrm{C}$ for 24 hours.

5.The medium available in the drillings was removed by a micropipette installed at 200 microliters. The drill was then washed once using the physiological saline solution at a rate of $300 \mu \mathrm{l}$ and using the ELISA-washer launcher.

6.Formulation of $10 \%$ Formaldehyde in 6.2.2.3 $(200 \mu \mathrm{l})$ for each hole to fix the bacterial membrane of the bacterial isolates on the internal surfaces of the plate and leave the dish for 30 minutes at room temperature $25^{\circ} \mathrm{C}$, and formaldehyde was removed from all the holes using a micro-pipette installed at $200 \mu 1$.

7.Turn the dish over a clean piece of gauze and set upside down to the next day at room temperature.

8.The crystal violet, recorded in 4.2.2.3, has been added at a rate of $200 \mu \mathrm{l}$ per hole for the production of the resulting biofilm.

9.Read the optical density using the ELISA reader at a wavelength of $590 \mathrm{~nm}$.

\section{Results}

The following bacteria are identified such as E. coli, P. mirabilis, P. aeruginosa, K.penumonia, after isolated and purified from agar samples based on microscopic characteristics of bacterial cells and morphological and plant Biochemical test including colony size, color, quenching, , biochemical test which used for the purpose of diagnosing each bacterium and conforming to the approved diagnostic systems [15] as shown in table (1) After isolation and diagnosis, four types of bacteria were isolated. As shown in Table 2, Escherichia coli 35 isolates were $31.8 \%, 20$ isolates were Proteus mirabilis with ratio $18.2 \%$, 16 Klebsiella pneumonia isolates with ratio $14.5 \%, \quad 14$ Pseudomonas aeruginosa with ratio $12.7 \%$ table (1). 
Bacteriological Study of the Bacteria Cause Urinary Tract Infection of Patients Admitted to Cardiac Care Unite a Baqubah General Teaching Hospital

Hanan Thamer Najim

Table (1): Microscopic and biochemical diagnosis of bacteria isolated from from UTIs.

\begin{tabular}{||c||c||c||c||c||}
\hline $\begin{array}{c}\text { Klebsiella } \\
\text { pneumoniae }\end{array}$ & $\begin{array}{c}\text { Pseudomonas } \\
\text { aeruginosa }\end{array}$ & $\begin{array}{c}\text { Proteus } \\
\text { mirabilis }\end{array}$ & $\begin{array}{c}\text { Escherichia } \\
\text { coli }\end{array}$ & $\begin{array}{c}\text { Isolates } \\
\text { Testes }\end{array}$ \\
\hline \hline- & - & - & - & Gram stain \\
\hline \hline+ & + & + & + & Catalase Test \\
\hline \hline- & + & - & - & Oxidase test \\
\hline \hline- & - & - & + & Methyl- red- test \\
\hline \hline+ & - & + & + & Vogesproskauer- test \\
\hline \hline+ & - & - & - & Citrate utilization- test \\
\hline \hline+ & + & $-/+$ & - & Motility Test \\
\hline \hline- & + & + & + & Urea hydrolysis- (urease test) \\
\hline+ & - & + & - &
\end{tabular}

Table (2): Frequencies and percentages of bacterial types.

\begin{tabular}{|l|c||c||}
\hline \multicolumn{1}{|c|}{ Bacteria } & No. & $\%$ \\
\hline \hline Escherichia coli & 35 & $31.8 \%$ \\
\hline \hline Proteus mirabilis & 20 & $18.2 \%$ \\
\hline \hline Klebsiella. Pneumoniae & 16 & $14.5 \%$ \\
\hline \hline Pseudomonas aeruginosa & 14 & $12.7 \%$ \\
\hline \hline Total & 85 & $77.27 \%$ \\
\hline
\end{tabular}

The results showed a clear variation in the

to the antibiotics used as shown in table(3). extent of the response of isolates under study

Table (3): Antibiotics sensitivity test for bacteria isolated from urinary tract infection.

\begin{tabular}{|c|c|c|c|c|c|c|c|c|c|c|}
\hline \multirow{2}{*}{$\%$} & \multirow{2}{*}{$\begin{array}{l}\text { Total } \\
\text { No. }\end{array}$} & \multicolumn{2}{|c|}{$\begin{array}{c}\mathrm{P} . \\
\text { aeruginosa }\end{array}$} & \multicolumn{2}{|c|}{ "K. pneumoniae } & \multicolumn{2}{|c|}{$\begin{array}{c}\mathrm{P} . \\
\text { mirabilis }\end{array}$} & \multicolumn{2}{|c|}{$\begin{array}{l}\text { E. } \\
\text { coli }\end{array}$} & \multirow[t]{2}{*}{ Antibiotics } \\
\hline & & $\%$ & No. & $\%$ & No. & $\%$ & No. & $\%$ & No. & \\
\hline 100 & 20 & 100 & 5 & 100 & 5 & 100 & 5 & 100 & 5 & Aztreonam \\
\hline 45 & 9 & 40 & 2 & 60 & 3 & 60 & 3 & 20 & 1 & Amikacin \\
\hline 75 & 15 & 100 & 5 & 80 & 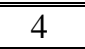 & 80 & 4 & 40 & 2 & Gentamicin \\
\hline 99 & 19 & 100 & 5 & 100 & 5 & 100 & 25 & 80 & 4 & Naldixic acid \\
\hline 100 & 20 & 100 & 5 & 100 & 5 & 100 & 5 & 100 & 5 & Co-Trimoxazol \\
\hline 100 & 20 & 100 & $\overline{5}$ & 100 & 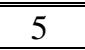 & 100 & 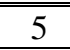 & 100 & 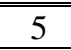 & Cefotaxime \\
\hline 70 & 14 & 60 & 3 & 80 & 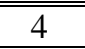 & 100 & 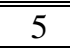 & 40 & 2 & Tetracycline \\
\hline 50 & 10 & 40 & 2 & 60 & 3 & 60 & 3 & 40 & 2 & Ciprofloxacin \\
\hline 80 & 16 & 80 & 4 & 60 & 3 & 100 & 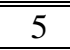 & 80 & 4 & Tobramycin \\
\hline$\overline{79.4}$ & 143 & 880 & 36 & 82.2 & 37 & 88.8 & 40 & 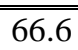 & 30 & Total \\
\hline
\end{tabular}

All E.coli isolates are resistant to antimicrobial Co-Trimoxazol, Cefotaxime, Aztreonam, Naldixic acid, Tobramycin, Ciprofloxacin, with ratio $100 \%$, $100 \%$,
$100 \%, 80 \%, 80 \%, 40$ respectively. As for the investigation of the production of the biofilm as shown in table (4),. The investigation results of the biofilm 
Bacteriological Study of the Bacteria Cause Urinary Tract Infection of Patients Admitted to Cardiac Care Unite a Baqubah General Teaching Hospital

Hanan Thamer Najim

production were shown in two ways, the medium of Congo- Red (CRA) and the method of ELISA is the best methods in detecting the biological membrane was the number of positive isolates was 20 isolates with a ratio $100 \%$ and then the Congo Red was 10 isolates $50 \%$.

Table (4): Biofilm production by bacteria isolated from urinary tract infection.

\begin{tabular}{||c||c||c||c||c||}
\hline$\%$ & Congo-Red method & $\%$ & ELISA method & Bacteria \\
\hline \hline $20 \%$ & 1 & $100 \%$ & 5 & E.coli \\
\hline \hline $60 \%$ & 3 & $100 \%$ & 5 & P.mirabilis \\
\hline \hline $60 \%$ & 3 & $100 \%$ & 5 & K.pneumoniae \\
\hline \hline $60 \%$ & 3 & $100 \%$ & 5 & Ps.aeruginosa \\
\hline $50 \%$ & 10 & $100 \%$ & 20 & Total \\
\hline
\end{tabular}

\section{Discussion}

Escherichia colonies have been shown on the MacConkey Agar medium with pink color due to fermentation of lactose sugar, solid, medium-sized, convex, dry, regular and negative for oxides test, positive for catalase test, negative for urea testing, positive in test the mandolin and the red instance, negative for the Voges-Proskauer test and is unable to consume the citrate.

Proteus mirabilis bacteria is characterized by the adoption of the phenomenon of Swarming movement on the medium of blood agar as a preliminary diagnosis, as well as pale colonies on the medium of MacConkey agar because of nonfermentation of lactose sugar and consumption of peptone source of nitrogen and the production of metabolic materials increase the value of $(\mathrm{pH})$, the medium, which in turn affects the Neutral red detector, makes the colonies pale colour, although this is common with other bacterial strains, but it is consistent with the phenomenon of the ripple movement [18].

As well as the smell of bacterial growth that is similar to the smell of fish on the same medium [19].Klebsiella pneumoniae bacteria was diagnosed with MacConkey agar medium in the fact that its large circular colonies, with irregular pink scales and mucus-containing capsule which were irregular, and their colonies on blood vessels were transparent and brilliant, unable to decompose blood [20].It also gave a negative result in an indole test and a positive for red Methyl test. The microscopic test showed that after a Gram stain dye was applied to a survey taken from the pure colonies on the nut medium, all the above isolates were negative to the gram chromosome as shown in table (1).

All E.coli isolates are resistant to antimicrobial Co-Trimoxazol, Cefotaxime, Aztreonam, Naldixic acid, Tobramycin, Ciprofloxacin, with ratio $100 \%, 100 \%$, $100 \%, 80 \%, 80 \%, 40 \%$ respectively. 
The results were consistent with [21]. The resistance of E. coli to Naldixic acid and Ciprofloxacin was $88 \%$ and $40 \%$, respectively., The results of the study for the antibiotic Tobramycin agree with results of [22], where the resistance ratio of E.coli of the antibiotic is $89.6 \%$. As for the antibiotic Tetracyclline, the resistance rate was $40 \%$. The results of the current study are consistent with the results of the study of the researcher [23] in Baghdad, where isolates were resistant to antagonism by $40 \%$, in the anti-Gentamycin , the resistance ratio of isolates was $40 \%$, percentage of resistance to E.coli isolates was $42 \%$, and the Gentamycin and Amikacin were $40 \%$. The results were close to [24]. The bacterial resistance to Amikacin 12.8\% . While P.mirabilis 100\% resistance against sensitivity, resistance to Co-Trimoxazol, Cefotaxime, and Naldixic Acid Tobramycin and Aztreonam and Gentamycin and Tetracyclline were all resistance by $100 \%$ as shown in table (3).

These above results were consistent with [25] which that the resistance of $P$. mirabilis to Cefotaxime and Tobramycin was $100 \%$ and $81 \%$ respectively. The results of Co-Trimoxazol were agreed with [26]. The resistance of the bacteria to the trimethoprim Antibiotic was $91 \%$ and it is in line with the results of the researcher [27] which the ratio of isolates to tetracycline Antibiotic was $100 \%$. As for the antimicrobial group Amikacin, the resistance was $60 \%$; for Ciprofloxacin Antibiotic, the resistance was $40 \%$; for the sensitivity of $\mathrm{K}$. pneumoniae, the resistance to the antibiotic, Cefotaxime, Aztreonam, Co-Trimoxazol, Naldixic acid 100\% , Tobramycin and Tobramycin, Gentamycin,Ciproflaxcin $\quad 80 \% \quad$, Tetracycline and Amikacin 60\% respectively. These results were agreed with [28] in her study in the city of Kirkuk on urinary tract patients where the resistance of K.pneumoniae to the anti-CoTrimoxazol is $(100 \%)$. the Tetracycline antibody was the resistance of $\mathrm{Kl}$. Pneumoniae is close to that of the researcher's [29] with a resistance rate of $84 \%$. This ratio is consistent with the findings of [30], that the rate of sensitivity of the isolates under study for Ciprofloxacin was $72.7 \%$, while for the Amikacin Antibiotic, it was consistent with [30]. The sensitivity of isolates was in the direction of Amikacin with ratio $81.8 \%$. For the bacteria of P.aeruginosa, the ratio of resistance to isolates for Ceftazidime, Aztreonam, Gentamicin, Co-Trimoxazol, and Naldixic acid was $100 \%$ as shown in table (3).The results agreed with [31], the resistance to Naldixic acid was $90.5 \%$ the result was agreed with [28] as the resistance of Gentamicin isolates was $100 \%$, while the results were agreed with [32] that the isolates were resistant to antimicrobial antagonism (Co-Trimoxazol) with a ratio $100 \%$, whereas Tobramycin and ciprofloxacin antibodies were resistant to P.aeruginosa bacteria were sensitive to $80 \%$ and $40 \%$ respectively. These results were close to [30].The antibiotics resistance 
Bacteriological Study of the Bacteria Cause Urinary Tract Infection of Patients Admitted to Cardiac Care Unite a Baqubah General Teaching Hospital

Hanan Thamer Najim

of Tobramycin was $66 \%$ and for the antiAmikacin antibody. The isolates resistance were $34 \%$ and the tetracycline Antibiotic was the resistance percentage of P.aeruginosa bacteria is $60 \%$. These results are in line with the results of the study conducted by the [33] in his study the a resistance ratio was 59\% The resistance of certain strains and strains of bacteria, especially the intestinal strains of the Escherichia coli Proteus mirabilis, Klebsell pneumoniae Pseudomonas aeruginosa, is attributed to many antibiotics, The indiscriminate and excessive use of Antibiotics by people has an effect on their resistance to these antibiotics, as well as the possibility of some genetic mutations in sites that control the encoding of antibiotic susceptibility . the results of the present study showed that the number of E.coli isolates produced in the red membrane of the Congo- Red method was one of five isolates with a ratio $10 \%$, while ELISA method the ratio was $100 \%$. For P.mirabilis bacteria, the number of isolates produced by the red membrane of the Congo- Red was 3 isolates with a ratio $60 \%$, whereas biofilm production of ELISA method in this study was $100 \%$. Whereas P.aeruginosa bacteria, the results showed that 3 isolates with a ratio $60 \%$ and $\% 100 \%$ by ELISA method. The investigation results of the biofilm production were shown in two ways, the medium of Congo- Red (CRA) and the method of ELISA is the best methods in detecting the biological membrane was the number of positive isolates was 20 isolations with a ratio $100 \%$ and then the Congo - Red was 10 isolations 50\%. There is a relationship between the ability of bacterial species to produce the membrane and its susceptibility to rehydration Female disease, since the bacterial species that possess biofilm resistant to many antibiotics and resistant to Opsonization and Phagocytosis as well as resistance to various environmental, in different proportions, including the production of Biofilm, which surrounds the colonies or colonies of bacterial cells to provide some kind of protection, and dose of Antibiotics and access to antibiotics bacterial cell for being a sticky substance. Conditions [34].

\section{References}

[1]Najar M.S , Saldanha C.L. and Banday K.A . (2009). Approach to urinary tract infections . Indihar Journal of Nephro logy .Oct ; 19( 4 ) : 128- 139.

[2]Chen,C.; Chen,Y.; Lu,P. Lin,W;. Chen,T and Lin,C.(2012). Proteus mirabilis urinary tract infection and bacteremia risk factor ,Clinical presentation and outcomes.J.of Microbiology.45(3): 228-236 .

[3]Naber, K.G., M.C. Bishop, T.E. Bjerklund-Johansen,H. Botto, M. Çek, M. Grabe, B. Lobel, J. Palou and P. Tenke .(2006). Guidelines on The Management of Urinary and Male Genital Tract Infections. European Association of Urology 2006.

[4]Laupland K. B. , Bagshaw S. M. , Gregson D. B. , Kirkpatrick A. W. , Ross T, Church DL. (2005) Intensive care Unit - 
Bacteriological Study of the Bacteria Cause Urinary Tract Infection of Patients Admitted to Cardiac Care Unite a Baqubah General Teaching Hospital

Hanan Thamer Najim

acquired urinary tract infection in a regional critical care System. Crit C ; R 60-5.

[5]Ramesh,N.,S.S.Chettipalayam,A.Velram ar ,R.P.Kurumandur and R.K.Velu ,2008.Urinary Tract Infection and Antimicrobial Susceptibility Patterns of Extended Spectrum of Beta Lactamase Producing Clinical Isolates.Advances in Biological Research 2(5_6):78_82,2008.

[6] Zorc, JJ., Levine, DA et al . ( 2005) . Clinical and demographic factors associated with urinary tract infection in young febrile infants. Pediatrics Sep; 116(3):644-8.

[7]Hibore . M. E. ( 2012 ). Prevalence and antibiotic susceptipiliry Patterns of selected bacterial Uropathogens among patients with urinaray Tract infection cases in wonji Hospital , Ethiopia , M. Sc. Thesis ,Sciences Department of Biology, School of Gradute studies Harmaya University.

[8]Kumar, A , Kamal C M ,Dermurari D, Singh S N. ( Aag . 2015 ). Ofloxacin and Nitro furantion sensitivity pattern In patient of Urinary Tract infection ( $\mathrm{U} T \mathrm{~T}$ ) at atertiary care teaching hospital ( LABCR ) International Archives of Bio Medical and clinical Research. July - Sept 2015 . vol 1; Issue I; $\mathrm{p}: 17$.

[9]Kariuki, S.; Revathi, G.; Corkill, J.; Kiiru, J.; Mwituria, J.; Mirza, N.; Hart, C.A.(2007). Escherichia coli from community-acquired urinary tract infections resistant to fluoroquinolones and extendedspectrum beta-lactams. J. Infect. Dev. Ctries. 1(3): 257-62.
[10]Lalitha,M.K.,2004.Manual

on AntimicrobialSusceptibilityTesting.http://w ww.scribd.com/doc/47234185/Antimicrobi al.Retrived:12/1/2011.time:8:10 PM. [11]Mathur, T. ; Singhal, S. ; Khan , S. etal. (2006) . Adverse effect of Staphylococci slime on in vitro activity of glycopeptides. Pn. J. Infeet. Dis 58 :353 - 7

[12]Holt,J.G.; Krieg, N.R.; Sneath, P.H.A.; Staley, J.A.; \& Williams, S.T.(1994). Bergy, s Manual Of Derminative Bacteriology. (9th) ed. Williams \& Wilkins. [13]Cowan, S.T. \& Steel, K.J. (2004) Manual for the identification of medical bacteria, 2nd ed. Cambridge university press, London.

[14] CLSI. Clinical and Laboratory Standards Institute.(2016). Performance Standards for Antimicrobial Susceptibility Testing; Twenty-Second Informational Supplement. CLSI Document M 100-S22. Wayne, PA: Clinical and Laboratory Standards Institute.

[15]Morello , J.K. ; Mizer , H. E and Granato , P.A. (2006). Laboratory Manual And work Book in Microbiology Application To Patient Care. 8thed. Mc Graw Hill .

[16]Freeman, D.J.; Falkiner,F.R. and Keane,C.T. (1989). New method for detecting slime production by coagulase negative staphylococci. J. Clin. Pathol. 42:pp.872-874.

[17]Sandoe,J.A. ; Witherden,I.R. ; Cove,J.H. ; Heritage,I. and Wilcox,M.H. (2003). Correlation between enterococcal 
Bacteriological Study of the Bacteria Cause Urinary Tract Infection of Patients Admitted to Cardiac Care Unite a Baqubah General Teaching Hospital

Hanan Thamer Najim

biofilms formation In vitro and medicaldevice related-infection In vitro.J.Med.Microbiol.2:pp.547-550. [18]Liaw, S. J.; AI, H.C.; HO, S.W.; Luh, K.T.; Wang, W.B. (2000). Inhibition of virulence factor expression and swarming differentiation in Proteus mirabilis by pnitrophenly glycerol. J. Med. Microbiol. 49(8): 725-731.

[19]Ong, C.L.Y.; Ulett, G.C.; Mabbett, A.N.; Beatson, S.A.; Webb, R.I.; Monaghan, W.; Nimmo, G.R.; Looke, D.F.; McEwan, A.G. and Schembri, M.A. 2008. Identification of type 3 fimbriae in uropathogenic Escherichia coli reveals a role in biofilm formation. J. Bacteriol. 190: 1054-1063.

[20]Levinson,W.(2004). Klebsiella in: Medical Microbiology \& Immunology examination \& Broad review 8th ed.TheMcCrow -Hill Companies Appleton \&Lang Int .Ed .U.S.A.

[21]Nanakaly, Z.G.A. (2010).

Characterization of Plasmid DNA Content and Antimicrobial Effect of Bile Salts on Esherichia coli Isolated from Urinary Tract Infection of Pregnant Woman. Higher Diploma . Thesis. College of Education / Scientific. University of Salahaddin.

[22]Mahmoud , Halah Mohammed .(2014) .Isolation, Identification and Adhesion Ability of Bacterial Species That Associated with Third Degree Ulcers in Type II Diabetic Patients . M.S.C, Thesis, the College of Science/ University of Baghdad .
[23]

Khosrow,

Taghreed

ABDULRAHMAN Kareem .(2013) .Detect genes ST,LT Toxin for Escherichia coli (E.coli) bacteria isolated from stool and urine sample by multiplex PCR Technique . M.S.C , Thesis,Engineering and biological techniques ,University of Baghdad .

[24]Al-dolaymi , Fatma yousif mater (2016) .Hits biological extracts aqueous and alcoholic vegetarian Matricaria recutita and Trigonella foenum-graecum against bacteria isolated from different clinical sources . M.S.C , thesis, College of Education for Pure Science/Diyala Universit.

[25]Yaseen, S.S. (2014). Statistical study of urinary tract infection at all in children under the age of five in the city of Kirkuk. Kirkuk Univ. J.9 Issue:2 : 22-42 .

[26]AL- Rajab , Ibrahim Adnan Mahmood .(2014) . Bacteriological study of Proteus mirabilis isolated from different clinical infectious source in AL- Muqdadiyah city.College of Education for Pure Science . M.S.C , thesis, DiyalaUniversity.

[27]Al Bayati, Sarwa Aziz Khaled (2010). Bacteriological and hereditary study of bacterial species Proteus spp. Causing urinary tract infections in the Tikrit area. Master Thesis. University of Tikrit, College of Science.

[28]AL-Jammaly , Modruka M. H. (2005) .Genitourinary Tract Infections of Women in Mosul City. M.S.C, Thesis.College of Science University of Mosul. 
Bacteriological Study of the Bacteria Cause Urinary Tract Infection of Patients Admitted to Cardiac Care Unite a Baqubah General Teaching Hospital

[29]AL-Khafaji, Marwa Hamid Mutashar (2008). The biopsy is performed by contaminated Klebsiella pneumoniae for external stabilizers and resistance to antimicrobials. Master Thesis, College of Science, University of Baghdad.

[30]Sarojamma, V and Ramakrishna, V.(2011). Prevalence of ESBL- producing Klebsiella pneumonia isolate in Tertiary Cary hospital. ,Article ID. 318348. 5 page . [31]Fadhel , RawanAmer .(2013) . Inhibition of Biofilm Production of Pseudomonas aeruginosa Isolated from Patients with Diabetic Foot Ulcer Grade II . M.S.C , thesis.College of Science The University of Mustansiriya.
[32]Abdullah, R.M. ; Samman, S.F. and AL-Shwaikh, A.M. (2010). Study the effectof antibiotic combination of betalactam and aminoglycoside with another group of antibiotics and their synergism effect .Journal of Arab Board of Health Spcialization, 11,.1..62-68.

[33]AL-NAQEEB ,BADIE SHARAF ALDEEN AZIZ .(2009) . A Study of some Virulence Factors for Pseudomonas aeruginosa Isolated from UTI . M.SC. Microbiology, the College of Science AL- Mustansiriya University . [34]BentzmannS.De and. Bordi, C. ( 2011) ; Hacking into bacterial biofilms : a new therapeutic challenge. Annals of Intensive Care, 1:19.pp.2-8. 